PENELITIAN

\title{
Kadar Serum Substansi P Pada Pemberian Klonidin Sebagai Ajuvan Analgesia Epidural
}

\author{
Serum levels of P substance On Clonidine As Adjuvant Epidural Analgesia \\ Karyadi \**, Yulia Wahyu Villyastuti ** \\ *RSUD Tarakan, Kalimantan Utara \\ **Bagian Anestesi dan Terapi Intensif Fakultas Kedokteran Universitas Diponegoro/ RSUP Dr. Kariadi Semarang. \\ $\triangle$ Korespondensi/Correspondence: karyadi_payanangga@yahoo.co.id
}

\section{ABSTRACT}

Background : Clonidine, when used in conjunction with a local anesthetic drug as a regional anesthetic techniques, could reduce the incidence of chronic postoperative pain. Peripheral and central sensitization is one of the mechanisms of transition of acute pain into chronic pain. Initial cascade that causes peripheral sensitization and central sensitization triggered by the presynaptic and post-synaptic release of excitatory neurotransmitters such as glutamate and substance $P$.

Objective: To compare serum levels of substance $P$ and the value of visual analogue scores at 0 and 12 hours post-operation between epidural analgesia with bupivacaine solely and bupivacaine with adjuvant clonidine

Methods : This study is a randomized double-blind study. Samples of 40 people divided into 2 groups, control group received epidural analgesia with bupivacaine solely and the treatment group received epidural analgesia bupivacaine with clonidine as adjuvant, analgesic was administered pre incisional continued for post-surgery. Serum levels of substance $P$ assessed preoperatively and 12 hours postoperatively in each group. While the VAS value was measured at 0 and 12 hours post-surgery

Results: There were significant differences in serum levels of substance $P$ in the form of a significant reduction at 12 hours postoperatively both the control and treatment groups. There was no significant difference serum levels of substance P between the control and treatment groups at 12 hours post-surgery. There was significant different of VAS values at 0 and 12 hours post-operation between the control and treatment groups

Conclusion : Epidural analgesia with bupivacaine and bupivacaine with adjuvant clonidine pre incision continued post operatively equally effective in lowering the levels of substance $P$ at 12 hours after surgery .

Keywords : epidural analgesia, clonidine, bupivacaine, substance $P$

\section{ABSTRAK}

Latar belakang: Klonidin ketika digunakan bersamaan dengan obat lokal anestesi 
sebagai teknik regional anestesi, bisa mengurangi kejadian nyeri kronik pasca operasi. Sensitisasi perifer dan sensitisasi sentral merupakan salah satu mekanisme terjadinya transisi nyeri akut menjadi nyeri kronik. Kaskade awal yang menyebabkan sensitisasi perifer dan sensitisasi sentral di picu oleh pelepasan neurotransmitter eksitatorik presinaptik dan pasca sinaptik seperti glutamat dan substansi $P$.

Tujuan: Membandingkan peningkatan kadar serum substansi P pada 12 jam pasca operasi dan nilai visual analog skor pada 0 dan 12 jam pasca operasi antara analgesia epidural dengan bupivakain murni dan bupivakain dengan ajuvan klonidin

Metode: penelitian ini merupakan penelitian acak tersamar ganda. Sampel 40 orang dibagi 2 kelompok, yaitu kelompok kontrol mendapat epidural analgesia dengan bupivacain murni dan kelompok kontrol mendapat epidural analgesia bupivakain ditambah ajuvan klonidin dimana pemberian analgesia dilakukan pra insisi dan dilanjutkan samapai pasca operasi. Kadar serum substansi P dinilai pra operasi dan 12 jam pasca operasi pada masing-masing kelompok perlakuan. Sedangkan nilai VAS diukur pada 0 dan 12 jam pasca operasi

Hasil: Terdapat perbedaan kadar serum substansi P berupa penurunan secara bermakna pada 12 jam pasca operasi baik pada kelompok kontrol dan perlakuan. Tidak terdapat perbedaan yang bermakna antara rerata kadar serum substansi $P$ antara kelompok kontrol dan perlakuan pada 12 jam pasca operasi. Terdapat perbedan nilai VAS secara bermakna pada 0 dan 12 jam pasca operasi antara kelompok kontrol dan perlakuan

Simpulan: epidural analgesia dengan bupivacain maupun dengan ajuvan klonidin yang diberikan pra insisi yang dilanjutkan pasca operasi sama-sama efektif menurunkan kadar substansi P pada 12 jam pasca operasi.

Kata kunci: analgesia epidural, klonidin, bupivakain, substansi P

\section{PENDAHULUAN}

Angka kejadian nyeri kronik pasca operasi dilaporkan bervariasi, sebagai contoh nyeri pasca operasi mastektomi, torakotomi, amputasi yang berlanjut menjadi nyeri kronik berkisar 50-70\%, dan $10 \%$ diantaranya mengalami nyeri yang sangat parah. ${ }^{1-4}$ Nyeri pasca operasi juga lazim terjadi setelah satu tahun pasca operasi abdomen bawah, sternotomi, histerektomi dan herniorapi dengan angka kejadian berkisar $25 \%$. $^{5-10}$

Pasien dengan nyeri pasca operasi yang hebat mempunyai resiko yang lebih besar untuk mengalami nyeri kronik sesudahnya. ${ }^{11-13}$ Terapi terhadap nyeri pasca operasi yang agresif diperkirakan bisa mengurangi resiko terhadap berkembangnya nyeri akut pasca operasi menjadi nyeri kronik. Preventative regional analgesia telah menunjukkan hasil yang menjanjikan meskipun data akan hal ini masih terbatas.

$$
\text { Proses inflamasi yang terjadi }
$$
sebagai akibat proses pembedahan 
merupakan proses interaksi bidireksional antara inflamasi klasik yang diperankan oleh sel-sel inflamatori dengan ujung sel saraf aferen yang mengeluarkan mediator inflamasi secara antidromik, seperti substansi P, Calsitonin gene related protein (CGRP), neurokinin A yang menyebabkan serangkaian respon inflamasi lokal akibat rangsangan nosiseptif yang berperan besar terhadap terjadinya inflamasi neurogenik. ${ }^{14-18}$ Inflamasi neurogenik yang ditandai dengan pelepasan dan peningkatan substansi P. ${ }^{19}$ Penghambatan pelepasan mediator inflamasi yang mengaktifasi saraf aferen baik diperifer maupun disentral oleh obat-obat analgesia yang diberikan perioperatif merupakan tujuan utama dalam pencegahan transisi nyeri akut menjadi nyeri kronik.

Klonidin, ketika digunakan bersamaan dengan obat lokal anestesi sebagai teknik regional anestesi, bisa mengurangi kejadian nyeri kronik pasca operasi. $^{20}$ Kaskade awal yang menyebabkan sensitisasi perifer dan sensitisasi sentral di picu oleh pelepasan neurotransmitter eksitatorik presinaptik dan pasca sinaptik seperti glutamat dan substansi P. ${ }^{21,22}$ Pada jaringan yang mengalami luka bakar kadar substansi $\mathrm{P}$ pada jaringan kulit deep partial thickness mulai meningkat setelah 4 jam dan mencapai puncaknya pada 12 dan 18 jam setelahnya. ${ }^{23}$ Klonidin mengurangi pelepasan substansi $P$ jika diberikan secara sentral. $^{24,25}$ Aktivasi reseptor $\alpha 2$ bisa menyebabkan penurunan influks $\mathrm{Ca}^{2+}$ kedalam ujung saraf, sehingga hal tersebut menyebabkan inhibisi pelepasan neurotransmiter termasuk substansi P dari ujung saraf. ${ }^{26}$

Penelitian ini bertujuan untuk melihat pengaruh penggunaan klonidin senagai ajuvan analgesia epidural perioperatif terhadap peningkatan kadar serum substansi P 12 jam pasca operasi dan juga nilai Visual analog skornya pada 0 dan 12 jam pasca operasi.

\section{METODE}

Penelitian ini termasuk jenis uji klinis acak tersamar ganda dengan tujuan mengetahui pengaruh pemberian adjuvan klonidin pada analgesia epidural perioperasi terhadap peningkatan kadar serum substansi $P$ 12 jam pasca operasi dan nilai VAS 0 dan 12 jam pasca operasi. Tempat penelitian di RSUP Dr. Kariadi pada periode Januari - Februari 2014. Populasi penelitian adalah Pasien yang menjalani operasi laparotomi di RSUP Dr. Kariadi. Sampel yang memenuhi kriteria inklusi dan eksklusi, menggunakan "consecutive sampling", berjumlah 20 orang, dibagi menjadi dua kelompok, yaitu: kelompok P1: Pemberian analgesi epidural bupivakain $0,25 \%$ pra insisi dilanjutkan bupivakain $0,125 \%$ infus kontinyu $5 \mathrm{cc} /$ jam pasca operasi;dan kelompok P2: Pemberian analgesi epidural perioperasi bupivakain $0,25 \%$ ditambah ajuvan klonidin dosis $75 \mu \mathrm{g}$ sebelum insisi dan bupivakain $0,125 \%$ ditambah klonidin 
$0,6 \mu \mathrm{g} / \mathrm{cc}$ infus kontinyu $5 \mathrm{cc} / \mathrm{jam}$ pasca operasi dilanjutkan bupivakain $0,125 \%$ infus kontinyu $5 \mathrm{cc} / \mathrm{jam}$ pasca operasi. Kriteria inklusi adalah : umur 16-65 tahun, Pasien dijadwalkan operasi laparotomi dengan status Fisik ASA I-II dan bersedia diikutkan dalam penelitian. Kriteria ekslusi adalah pasien dengan hipertensi tidak terkontrol, angina pektoris, gagal jantung, pengobatan antidepresan trisiklik, agonis alfa2 atau opioid, ada kontra indikasi epidural anaestesi, dan tidak memiliki riwayat sakit autoimun

Sebelum dilakukan pembiusan pasien diambil darahnya untuk mengukur kadar serum substansi $\mathrm{P}$ awal. Pasien diberikan premedikasi midazolam $0,8 \mathrm{mg} / \mathrm{kgBB}$. Kemudian pasien dipasang kateter epidural dengan teknik lose of resistance, epidural space diidentifikasi pada vertebra lumbal 1-2 atau L1-T12, kemudian kateter dimasukkan 3-5 cm dari epidural space. Test dose diberikan dengan lidokain ditambah epineprine 1:200000 3cc. Induksi dilakukan dengan propofol 22,5 $\mathrm{mg} / \mathrm{kgBB}$, fentanil $2 \mu \mathrm{g} / \mathrm{kgBB}$, vekuronium $\quad 0,1 \quad \mathrm{mg} / \mathrm{kgBB}$. Pemeliharaan anestesi dengan isoflurane $1 \mathrm{MAC}$, analgesia diberikan dengan bupivakain $0,25 \% 16$ cc pada kelompok kontrol dan bupivakain 0,25\% 16 cc ditambah ajuvan klonidin $75 \mu \mathrm{g}$ diberikan 15 menit sebelum insisi dengan target dermatom T5-6. Pasca operasi pasien diberikan analgesi epidural bupivakain $0,125 \%$ infus kontinyu 5cc/jam pada kelompok P1 dan bupivakain $0,125 \%$ ditambah klonidin $0,6 \mu \mathrm{g} / \mathrm{cc}$ infus kontinyu $5 \mathrm{cc} /$ jam pada kelompok P2. Kadar serum substansi $\mathrm{P}$ diperiksa 12 jam pasca operasi. Nilai VAS dinilai pada jam ke 0 dan 12 jam pasca operasi pada saat istirahat dan pada saat bergerak.

\section{HASIL}

Karakteristik Sebaran Umur , Jenis Kelamin, jenis operasi dan lama operasi lihat tabel 1.

Nilai dinyatakan dengan rerata dan simpang baku. Uji independent $t$ dan uji pearson Chi-square terhadap karakteristik kedua kelompok menunjukkan perbedaan tidak bermakna $(p>0,05)$, sehingga dapat dibandingkan.

Untuk kadar serum substansi $\mathrm{P}$ pra operasi dan 12 jam pasca operasi antara kelompok kontrol dan perlakuan didapatkan hasil seperti pada tabel 3.

Dari data diatas dengan uji paired $t$ didapatkan Kadar serum substansi P pada kelompok kontrol pra operasi dan 12 jam pasca operasi didapatkan hasil penurunan yang berbeda bermakna $(p<0,05)$. Sedangkan untuk kelompok perlakuan dengan uji paired $t$ untuk kadar serum substansi $\mathrm{P}$ sebelum dan 12 jam pasca operasi didapatkan hasil penurunan yang juga berbeda bermakna $(\mathrm{P}<0,05)$.

Untuk perbandingan rerata kadar serum substansi $\mathrm{P}$ pra operasi antara kelompok kontrol dan perlakuan 
dengan uji independent $t$ didapatkan nilai tidak berbeda bermakna $(p>0,05)$ sedang untuk perbandingan kadar serum substansi P 12 jam pasca operasi antara kelompok kontrol dan perlakuan dengan uji independent $t$ juga didapatka hasil yang tidak berbeda bermakna $(p>0,05)$.

Untuk perbandingan nilai VAS pada 0 dan 12 jam pasca operasi pada kelompok kontrol dan perlakuan didapatkan hasil seperti pada tabel 4 .

Dari data diatas didapatkan nilai VAS pada 0 dan 12 jam pasca operasi dengan uji mann whitney pada kelompok kontrol dan perlakuan berbeda bermakna $(p<0,05)$.

\section{PEMBAHASAN}

Penelitian ini dilakukan untuk melihat kadar serum substansi $\mathrm{P}$ pada pasien yang menjalani operasi laparotomi yang diberikan analgesia epidural bupivakain $0,25 \% \quad 15$ menit sebelum insisi sebagai preemptif analgesia dan dilanjutkan dengan bupivakain $0,125 \%$ infus kontinyu dibandingkan dengan kelompok perlakuan yang diberikan bupivakain 0,25\% ditambah ajuvan klonidin $75 \mu \mathrm{g}$ dan dilanjutkan bupivakain $0,125 \%$ ditambah klonidin $0,6 \mu \mathrm{g} / \mathrm{cc}$ infus kontinyu.

Substansi P disintesis di ribosom dimana protein yang lebih besar dirubah secara enzimatik menjadi dekapeptida. Peptida ini tersebar luas di sistem saraf pusat maupun saraf perifer.
Meskipun substansi P dipahami berasal dari neuronal sebagaimana terjadi pada proses inflamasi neurogenik, penelitian pada tikus menunjukkan substansi $\mathrm{P}$ juga diproduksi oleh sel inflamasi seperti makrofag, eosinofil, limfosit dan sel dendritik. ${ }^{27-30}$ Substansi $P$ meningkatkan proliferasi limfosit dan produksi imunoglobulin, meningkatkan sekresi sitokin dari limfosit, monosit, makrofag dan sel mast. ${ }^{27-30}$ Substansi $\mathrm{P}$ merangsang pelepasan mediator inflamasi seperti sitokin, oxygen radicals, derivat asam arakidonat dan histamin, menstimulasi sebukan lekosit pada daerah perlukaan sehingga memperkuat respon inflamasi. ${ }^{31}$

Pada neurotransmisi nyeri substansi $\mathrm{P}$ berperan dalam proses sensitisasi perifer dan sensitisasi sentral. Substansi P dan glutamat merupakan neurotransmiter eksitatorik pre dan pasca sinaptik. Menariknya, sekitar $80 \%$ SP yang di hasilkan di DRG di didistribusikan ke perifer dibandingkan ke sentral. Beberapa enzim berperan dalam metabolisme SP diperifer yakni, netral endopeptidase dan angiotensin converting enzime.

\begin{tabular}{lcr}
\multicolumn{1}{c}{ Interaksi } & antara & SP dan \\
reseptornya & secara & langsung \\
menyebabkan & vasodilatsi & dan
\end{tabular} meningkatkan permeabilitas pembuluh darah sehingga terjadi ekstravasasi plasma dan degranulasi mastosit. Sel mast kemudian melepaskan histamin, yang akan memperkuat proses vaskuler tadi dan mengaktivasi nosiseptor. 
Limfosit, granulosit, dan makrofag mempunyai reseptor untuk SP dan selsel ini bisa distimulasi untuk memproduksi sitokin. Makrofag yang distimulasi oleh SP bisa menghasilkan mediator inflamasi PGE2, tromboksan, dan juga sitokin proinflamasi seperti IL -1, IL-6, TNF alpha. Kemudian semua proses molekuler ini akan menyebabkan produksi dan pelepasan SP, sehingga proses ini merupakan sebuah lingkarang setan. Lebih lanjut mekanisme ini tidak hanya melibatkan serabut saraf pada jaringan luka tetapi juga meluas ke sekitar jaringan luka, sehingga menyebabkan hiperalgesia sekunder. ${ }^{32,33,34}$

Pemilihan metode pemberian analgesia epidural secara infus kontinyu pada penelitian ini adalah untuk menjaga level analgesia dan meminimalisir efek samping respirasi maupun kardiovaskuler yang bisa terjadi pada pemberian dengan metode bolus intermiten. Disamping substansi $\mathrm{P}$ pada penelitian ini juga dilihat nilai VAS antara kelompok kontrol dan perlakuan pada 0 dan 12 jam pasca operasi.

Pada penelitian ini perbedaan kadar serum substansi P pra operasi dan 12 jam pasca operasi baik untuk kelompok kontrol maupun perlakuan didapatkan perbedaan yang bermakna. Substansi P merupakan neurotransmiter nyeri yang utama, penurunan kadar serum substansi P baik pada kelompok kontrol dan perlakuan juga sesuai dengan rerata nilai VAS yang rendah
( nilai VAS < 4) baik pada kelompok kontrol maupun perlakuan. Pada neurotransmisi nyeri substansi $P$ berperan dalam proses sensitisasi perifer dan sensitisasi sentral dimana sensitisasi perifer dan sensitisasi sentral merupakan salah satu mekanisme terjadinya transisi nyeri akut menjadi nyeri kronik. Hal ini sesuai dengan penelitian sebelumnya yang dilakukan oleh $\mathrm{Wu}$ dkk dimana bupivakain epidural yang diberikan pra insisi memberikan efek analgesia yang lebih baik pasca operasi abdomen atas pada hari pertama pasca operasi. ${ }^{35}$ Hasil penelitian ini juga mempunyai kesesuaian dengan penelitian yang memberikan analgesia epidural sebelum torakotomi dan dilanjutkan pasca operasi dimana ditemukan kejadian nyeri kronik setelah 6 bulan pasca operasi yang lebih sedikit dibandingkan dengan pasien yang diberikan patient controlled analgesia intravena opioid untuk analgesia pasca operasi. ${ }^{36}$ Begitu juga dengan penelitian pada pasien yang menjalani operasi reseksi kolon, pemberian analgesia epidural kontinyu perioperatif bisa menurunkan risiko perkembangan nyeri yang persisten sampai satu tahun dibandingkan pasien yang mendapatkan analgesia secara intravena. ${ }^{37}$ Blok paravertebra yang dilakukan sebelum insisi mengurangi prevalensi dan intensitas nyeri pada 12 bulan pasca operasi mammae juga mempunyai kesesuaian dengan penelitian ini. ${ }^{38}$

Dari data diatas bisa dilihat efek 
Tabel 1. Karakteristik Sebaran Umur, Jenis Kelamin, jenis operasi dan lama

\begin{tabular}{|c|c|c|c|}
\hline \multirow{3}{*}{$\frac{\text { Variabel }}{\text { Umur }}$} & \multicolumn{2}{|l|}{ Kelompok } & \multirow{3}{*}{$\frac{\mathbf{p}}{0,238^{\S}}$} \\
\hline & \multicolumn{2}{|c|}{\begin{tabular}{l|l} 
perlakuan & Kontrol
\end{tabular}} & \\
\hline & $48,35 \pm 6,327$ & $51,15 \pm 8,318$ & \\
\hline \multicolumn{4}{|l|}{ Jenis kelamin } \\
\hline Laki-laki & $9(45 \%)$ & $5(25 \%)$ & $0,185^{¥}$ \\
\hline Perempuan & $11(55 \%)$ & $15(75 \%)$ & \\
\hline \multicolumn{4}{|l|}{ Jenis operasi } \\
\hline $\begin{array}{l}\text { Laparatomi } \\
\text { eksplorasi }\end{array}$ & $9(45 \%)$ & $5(25 \%)$ & $0,185^{¥}$ \\
\hline SOU CSS & $11(55 \%)$ & $15(75 \%)$ & \\
\hline Lama operasi (menit) & $180,25 \pm 8,711$ & $182,80 \pm 7,647$ & $0,331^{\S}$ \\
\hline
\end{tabular}

Keterangan :

${ }^{\S}$ Independent $t$ Test ${ }^{¥}$ Pearson Chi-Square

Tabel 3. Hasil uji beda Substansi P pra operasi dan 12 jam pasca operasi

\begin{tabular}{|l|l|l|l|}
\hline \multirow{2}{*}{ Kelompok } & \multicolumn{2}{|c|}{ Substansi P } & \multirow{2}{*}{ p } \\
\cline { 2 - 3 } & \multicolumn{1}{|c|}{ Pre } & \multicolumn{1}{c|}{ Post } & \\
\hline Perlakuan & $90,66 \pm 14,528$ & $57,18 \pm 9,971$ & $0,000^{\text {व }}$ \\
\hline Kontrol & $89,37 \pm 11,972$ & $62,46 \pm 8,485$ & $0,000^{\alpha}$ \\
\hline & $0,760^{\S}$ & $0,079^{\S}$ & \\
\hline
\end{tabular}

Keterangan $:^{\circledR}$ Paired t Test ${ }^{\S}$ Independent $t$ Test

Tabel 4. Nilai VAS pada 0 dan 12 jam pasca operasi

\begin{tabular}{|l|l|c|c|}
\hline \multirow{2}{*}{ Variabel } & \multicolumn{2}{|c|}{ Kelompok } & \multirow{2}{*}{ p $^{£}$} \\
\cline { 2 - 3 } & \multicolumn{1}{|c|}{ perlakuan } & Kontrol & \\
\hline VAS 0 & $1,60 \pm 0,503$ & $1,55 \pm 0,510$ & 0,752 \\
\hline VAS 12 & $1,10 \pm 0,308$ & $1,40 \pm 0,503$ & 0,031 \\
\hline
\end{tabular}

Keterangan : 
pre-emptive dari pemberian analgesia epidural yang dilanjutkan sebagai analgesia pasca operasi baik untuk kelompok kontrol maupun kelompok perlakuan mempunyai kesesuaian dengan penelitian-penelitian sebelumnya. Hal diatas dimungkinkan karena pemberian analgetik sebelum adanya stimulus nyeri akut lebih efektif meminimalisir perubahan di kornu dorsalis medula spinalis yang dihubungkan dengan sensitisasi sentral dibandingkan pemberian analgetik yang sama tersebut diberikan setelah stimulus nyeri akut tersebut sudah terjadi. ${ }^{37}$ karena sensitisasi sentral tidak hanya berkaitan dengan insisi kulit tetapi juga perlukaan jaringan yang luas selama operasi dan inflamasi pasca operasi maka perhatian telah bergeser dari yang hanya intervensi tunggal sebelum insisi (pre-emptive) ke preventive analgesia dimana pada teknik ini pemberian intervensi analgesia yang sama dilanjutkan selama stimulus yang berpotensi menyebabkan proses sensitisasi masih ada, yakni sampai pasca operasi. ${ }^{39}$ Jika kita lihat desain penelitian ini dengan fakta diatas maka terlihat kesesuaian dengan adanya penurunan yang bermakna dari kadar serum substansi P baik pada kelompok kontrol maupun perlakuan.

Pemberian ajuvan klonidin pada penelitian ini juga menunjukkan peningkatan efikasi analgesia sebagaimana penelitian sebelumnya. ${ }^{40}$ Dimana nilai rerata VAS antara kelompok kontrol dengan perlakuan berbeda secara bermakna. Klonidin merupakan $\alpha 2$ agonis, salah satu ajuvan yang sering digunakan baik pada anestesi spinal maupun epidural. $\alpha 2$ agonis dimungkinkan memberikan aktifitas analgesinya pada medula spinalis.

Untuk uji beda kadar serum substansi P antara kelompok perlakuan dengan kontrol didapatkan nilai rerata yang berbeda tidak bermakna. Hal ini dimungkinkan karena pemberian analgesia epidural baik pada kelompok kontrol maupun perlakuan mempunyai mempunyai efek pre-emptive dan preventive yang baik. Dengan teknik seperti ini dimungkinkan penghambatan aferen yang cukup sebelum irisan operasi yang berlanjut sampai pasca operasi sehingga mengurangi rentetan rangsangan nosisepsi yang menyebabkan sensitisasi sentral. Sehingga meskipun bupivakain diberikan ajuvan klonidin, dimana klonidin sendiri mempunyai efek mengurangi pelepasan substansi $P$ tetapi tidak lebih efekif dalam mencegah terjadinya sensitisasi sentral sebagaimana dilihat dari kadar serum substansi P yang merupakan neurotransmiter utama terjadinya sensitisasi sentral dibanding bupivakain murni.

\section{SIMPULAN}

Dari hasil penelitian terhadap 40 pasien yang menjalani operasi laparotomi yang mendapatkan analgesia epidural dengan bupivakain 
pada kelompok kontrol dan bupivakain dengan ajuvan klonidin sebelum insisi dan dilanjutkan pasca operasi secara infus kontinyu keduanya bisa menurunkan kadar serum substansi P secara bermakna. Pemberian ajuvan klonidin pada bupivakain yang diberikan pra insisi yang dilanjutkan pasca operasi tidak menunjukkan perbedaan yang bermakna terhadap penurunan kadar serum substansi $\mathrm{P}$ dibandingkan dengan pemberian bupivakain murni sebagai epidural analgesia dengan cara pemberian yang sama.

\section{DAFTAR PUSTAKA}

1. Kehlet H, Jensen TS, Woolf CJ. Persistent postsurgical pain: risk factors and prevention. Lancet 2006; 367: 1618-25

2. Dworkin RH, McDermott MP, Raja SN. Preventing chronic postsurgical pain: how much of a difference makes a difference? Anesthesiology 2010; 112: 516-8

3. Katz J, Seltzer Z. Transition from acute to chronic postsurgical pain: risk factors and protective factors. Expert Rev Neurother 2009; 9: 72344

4. Gartner R, Jensen MB, Nielsen J, Ewertz M, Kroman N, Kehlet H. daPrevalence of and factors associated with persistent pain following breast cancer surgery. JAMA 2009; 302: 1985-92

5. Katz J, Cohen L. Preventive analgesia is associated with reduced pain disability 3 weeks but not 6 months after major gynecologic surgery by laparotomy. Anesthesiology 2004; 101:169-74

6. Bruce J, Poobalan AS, Smith WC,
Chambers WA. Quantitative assessment of chronic postsurgical pain using the McGill Pain Questionnaire. Clin J Pain 2004; 20:70-5

7. Kalso E, Mennander S, Tasmuth T, Nilsson E. Chronic poststernotomy pain. Acta Anaesthesiol Scand 2001; 45: 935-9

8. Bay-Nielsen M, Perkins FM, Kehlet H. Pain and functional impairment 1 year after inguinal herniorrhaphy: a nationwide questionnaire study. Ann Surg $2001 ; 233: 1-7$

9. Haythornthwaite JA, Raja SN, Fisher B, Frank SM, Brendler $\mathrm{CB}$,Shir Y. Pain and quality of life following radical retropubic prostatectomy. J Urol 1998; 160: 1761-4

10. Gottschalk A, Smith DS, Jobes DR, et al. Preemptive epidural analgesia and recovery from radical prostatectomy: a randomized controlled trial. JAMA 1998; 279: 1076-82

11. Perkins FM, Kehlet H. Chronic pain as an outcome of surgery. A review of predictive factors. Anesthesiology 2000; 93: 1123-33

12. Pluijms WA, Steegers MA, Verhagen AF, Scheffer GJ, WilderSmith OH. Chronic postthoracotomy pain: a retrospec-tive study. Acta Anaesthesiol Scand 2006; 50: 804-8

13. Katz J, Jackson M, Kavanagh BP, Sandler AN. Acute pain after thoracic surgery predicts long-term post-thoracotomy pain. Clin J Pain 1996; 12:50-5

14. Hagains CE, Trevino LA, He JW, Liu H, Peng YB. Contributions of dorsal root reflex and axonal reflex to formalin-induced inflammation. Brain Res 2010; 1359:90-7

15. Foreman JC. Peptides and 
neurogenic inflammation. $\mathrm{Br}$ Med Bull 1987; 43: 386.

16. Hinsey JC, Gasser HS. The component of the dorsal root mediating vasodilation and the Sherrington contracture. Am J Physiol 1930; 92: 679

17. Chahl LA. Antidromic vasodilation and neurogenic inflammation. Pharmacol Ther 1988; 37: 275-300.

18. Cavagnaro J, Lewis RM. Bidirectional regulatory circuit between the immune and neuroendocrine systems. Year Immunol 1989; 4: 241-252.

19. Lambiase A, Bonini S, Micera A, Tirassa P, Magrini L, Bonini S, Aloe L. Increased plasma levels of substance $P$ in vernal keratoconjunctivitis. Investigative opthalmology \& visual science 1997;10(38):2161-64

20. Searle RD, Simpson KH.Cronic post-surgical pain. Cont Edu Anaesth Crit Care \& Pain. 2010;10 (1):12-14.

21. Coderre TJ, Melzack R. Central neural mediators of secondary hyperalgesia following heat injury in rats: neuropeptides and excitatory amino acids. Nerurosci Lett 1991;131:71-4

22. Ferreira SH, Lorenzetti BB. Glutamate spinal retrograde sensitization of primary sensory neurons associated with nociception. Neuropharmacology 1994;33:1479-85

23. Papp A, Valtonen P. Tissue substance $P$ level in acute experimental burns.Burns 2006;32:842-45

24. Kamisaki Y, Hamada T, Maeda K, Ishimura $M$, Itoh $T$. Presynaptic alpha-2 adrenoceptors inhibit glutamate release from rat spinal cord synaptosome. J Neurochem
1993;60:522-6

25. Gong H, Liu Q, Yang X, Liu Z, Liu G, Li Z. Effects of selective alpha 2 -adrenoreseptor stimulation on capsaicin-evoked substance $P$ release from primary cultured dorsal root ganglion neurons. Pharmazie 2010; 65: 202-5

26. Gertler, R., Brown, H.C., Mitchell, D.H. and Silvius, E.N. (2001) Dexmedetomidine: a novel sedative -analgesic agent. Baylor University Medical Center Proceedings 14, 1321.

27. Bost KL, Breeding SA, Pascual DW. Modulation of the mRNAs encoding substance $\mathrm{P}$ and its receptor in rat macrophages by LPS. Reg Immunol 1992; 4(2):105 -112 .

28. Killingsworth CR, Shore SA, Alessandrini F, Dey RD, Paulauskis JD. Rat alveolar macrophages express preprotachykinin gene-I mRNA-encoding tachykinins. Am J Physiol 1997; 273(5 Pt 1):L1073L1081

29. Joos GF, Germonpre PR, Pauwels RA. Role of tachykinins in asthma. Allergy 2000; 55(4):321-337.

30. Holzer P, Holzer-Petsche U. Tachykinins in the gut. Part II. Roles in neural excitation, secretion, and inflammation. Pharmacol Ther 1997;73(3):219263.

31. O'connor TM, O'Connell J, O'Brien DI, Goode T, Bredin CP, Shanahan F. The Role of substance $\mathrm{P}$ in inflammatory disease. Journal of cellular physiology. 2004;201: 167-180

32. Trivedi M, Bergata N.V. Serum concentration of substance $P$ in cholelitiasis. Annals of hepatology. 2010; 9(2):177-180

33. Lambiase A, Bonini S, Micera A, Tirassa P, Magrini L, Aloe L, et al. 
Increase plasma level of substance $\mathrm{P}$ in vernal keratoconjungtivitis.investigative opthalmology and visual science. 1999;32(10):2161-64.

34. Woolf CJ, Salter MW. Neuronal plasticity: increasing the gain in pain. Science 2000;288(5472):1765 -9 .

35.Wu CT, Yeh CC, Yu JC, Lee MM, Tao PL, Ho ST, et al. Pre-incisional epidural ketamine, morphine and bupivacaine combined with epidural and general anaesthesia provides pre -emptive analgesia for upper abdominal surgery. Acta Anaesthesia Scand 2000; 44:63-8

36. Senturk M, Ozcan PE, Talu GK et al. The effects of three different analgesia techniques on long-term postthoracotomy pain. Anesth Analg 2002;94(1):11-5

37.Lavand'homme P, De Kock M, Waterloos H. Intraoperative epidural analgesia combined with ketamine provides effective preventive analgesia in patients undergoing major digestive surgery. Anesthesiology 2005;103(4):813-20

38. Kairaluoma PM, Bachmann MS, Rosenberg $\mathrm{PH}$ et al. Preincisional paravertebral block reduces the prevalence of chronic pain after breast surgery. Anest Analg 2006;103(3):703-8

39. Dahl JB, Moiniche S. Pre-emptive analgesia. Br Med Bull 2004;71:1327

40.Jyothi, H. Verma, S. Safiya: A Prospective Randomised Study Of Combination Of Epidural Bupivacaine With Clonidine And Bupivacaine For Postoperative Analgesia. The Internet Journal of Anesthesiology 2012; 30(2). DOI: $10.5580 / 2 b 74$ 